\title{
Heavy Metal Contamination of Surface Soil in Relationship to Land Use Patterns: A Case Study of Benue State, Nigeria
}

\author{
Christopher Iorfa Adamu, Therese Ntonzi Nganje
}

Department of Geology, University of Calabar, Calabar, Nigeria.

Email: ntonzi@yahoo.com

Received April 26 $6^{\text {th }}, 2010$; revised May $14^{\text {th }}, 2010$; accepted June $1^{\text {st }}, 2010$.

\begin{abstract}
A detailed investigation was conducted on the relationship between land use patterns and trace metal content in surface soils of the Benue State to assess soil environmental quality. Results revealed that metals levels were generally high in mineralized and urban soils and lower in agricultural soils whilst forest soils were lease by anthropogenic pollution. Mineralized soils developed from weathered sulphides were rich in lead $(\mathrm{Pb})$, zinc $(\mathrm{Zn})$, and cadmium $(\mathrm{Cd})$. Urban soils accumulated copper $(\mathrm{Cu}), \mathrm{Zn}$, and Cd most probably from refuse dumps, gasoline combustion and farming. Agricultural soils were enriched in arsenic (As) and to a lesser degree $\mathrm{Pb}$ and $\mathrm{Cd}$ originating most probably from the application of pesticides, manure and fertilizers. A pollution index (PI) based on plant-tolerant contamination levels, indicates that multi-element contamination in soils is low and implies that the sampled soils could be cultivated for crop production especially away from point sources of pollution. The degree of anthropogenic pollution was high for As (80\%), and $\mathrm{Pb}$ (54\%), moderate for $\mathrm{Zn}(47 \%), \mathrm{Cd}(40 \%)$, and low for $\mathrm{Cu}(27 \%)$. Correlations $(r)$ are significant between $\mathrm{Zn}$ - $\mathrm{Pb}$ (0.7), $\mathrm{Cu}$-As (0.6) in mineralized soils, between $\mathrm{Zn}-\mathrm{Cu}$ (0.64), $\mathrm{Zn}$-Cd (0.5), $\mathrm{Cu}$-Cd (0.6), in urban soils, $\mathrm{As}-\mathrm{Cd}(0.61)$, in agricultural soils and $\mathrm{Zn}-\mathrm{Pb}(0.82)$ in forest soils. These distinct relationships indicate a common source or similar geochemical control. Based on the overall evaluation, recommendation in respect of contamination, control and monitoring strategies as well as land use planning in the study area are presented.
\end{abstract}

Keywords: Heavy Metals, Pollution Index, Surface Soil, Land Use

\section{Introduction}

Soil is not only a medium for plants growth or waste disposal but also a transmitter of many pollutants to surface water, ground water, atmosphere and food. Soil pollution may threaten human health not only through its effect on hygiene quality of food and drinking water, but also through its effect on air quality. Little attention has been paid to soil pollution compared to food in the past [1]. More recently, however, the impact of soil pollution on soil functions and the biosphere has been increasingly emphasized by the government, environmental protection agencies and the public [2]. In particular significant advances have been made in respect of mining related heavy metal pollution of the soil in different parts of the world [3-7].

However, a survey of heavy metals indicates that they do accumulate in soils in some localized areas of human activities as compared to areas that have remained under virgin conditions [8]. In addition to mining activities, concentration of heavy metals in terrestrial environment have increased significantly as a result of human activities such as emissions from thermal power stations, waste disposal, soil amendments and vehicle traffic/road infrastructures [9]. Other non point sources of contamination affecting predominantly agricultural soils include inputs such as, fertilisers, pesticides, sewage sludge, organic manures and composts $[10,11]$. Some of the anomalous accumulation may also be geology-related [12].

A knowledge of the level and distribution of heavy metals in soils can play a key role in land use planning, the designing of control strategies to achieve a better environmental quality as well as a key to effective management of soil quality especially in rapidly growing area such as Benue State. Unfortunately there is little information on the geochemical distribution and behavior of heavy metals in the developing countries because heavy metals analysis is rarely carried out in routine monitoring 
of soil quality [13].

Uncontrolled inputs of heavy metals are undesirable because once accumulated in the soil they are generally very difficult to remove and are potentially harmful. Subsequent problems may include toxicity to plants, surface and groundwater contamination as well as dietary exposure to man and animals. The impact of contamination extends beyond the contaminated environment $[14$, $15]$.

In Nigeria, like many other developing countries, more metal-containing waste are constantly being released into environment through urbanization as well as industrial, mining, and agricultural activities. Heavy metals are also emitted during high temperature processes such as oil combustion in automobiles, electric power stations, industrial plants as well as refuse incineration [16]. The objectives of this study include the determination of the levels of selected heavy metals in surface soils of the Benue state in relation to land use patterns and geology and contamination.

\section{Selection and Description of Sites}

The Benue state has a rapidly growing population of over 4.2 million people and total land area of over $40,000 \mathrm{~km}^{2}$ [17]. The state is dominantly an agricultural state. More than $70 \%$ of the land is used for agriculture while mining, urban centres and forest reserves are also significant. The potential inputs of heavy metals above the geogenic background values in the state may be rel- ated to these human activities. Therefore, four sites (Figure 1) were selected to represent the dominant land use pattern (or sources of heavy metals) as follows:

Mineralized soil from Arufu (Site A)

Urban soil from Makurdi (Site B)

Agricultural soil from Ugba (Site C)

From a government forest reserve (near Makurdi Site D)

Site A (Arufu) is an area well known for its $\mathrm{Pb}-\mathrm{Zn}$ mineralization in the middle Benue Trough. The area is important mainly for the mining of $\mathrm{Pb}-\mathrm{Zn}$ and associated $\mathrm{Ag}$. The site was chosen because the mineralization and mining activities have lead to the occurrence of many abandoned mines (galleries) and tailings scattered around the open mines pits. These can cause the contamination of the local environments as elements could be released to the soil at greater rate than would occur by the natural weathering of barren or underlying parent material. Samples collected here were termed mineralized soils.

Site B (Makurdi) is the capital city of Benue State. Since becoming the capital city in 1976 it has witnessed tremendous increase in human population and activities due to abundant and expanding economic opportunities. Of its total land area of about $200 \mathrm{~km}^{2}$, built up areas

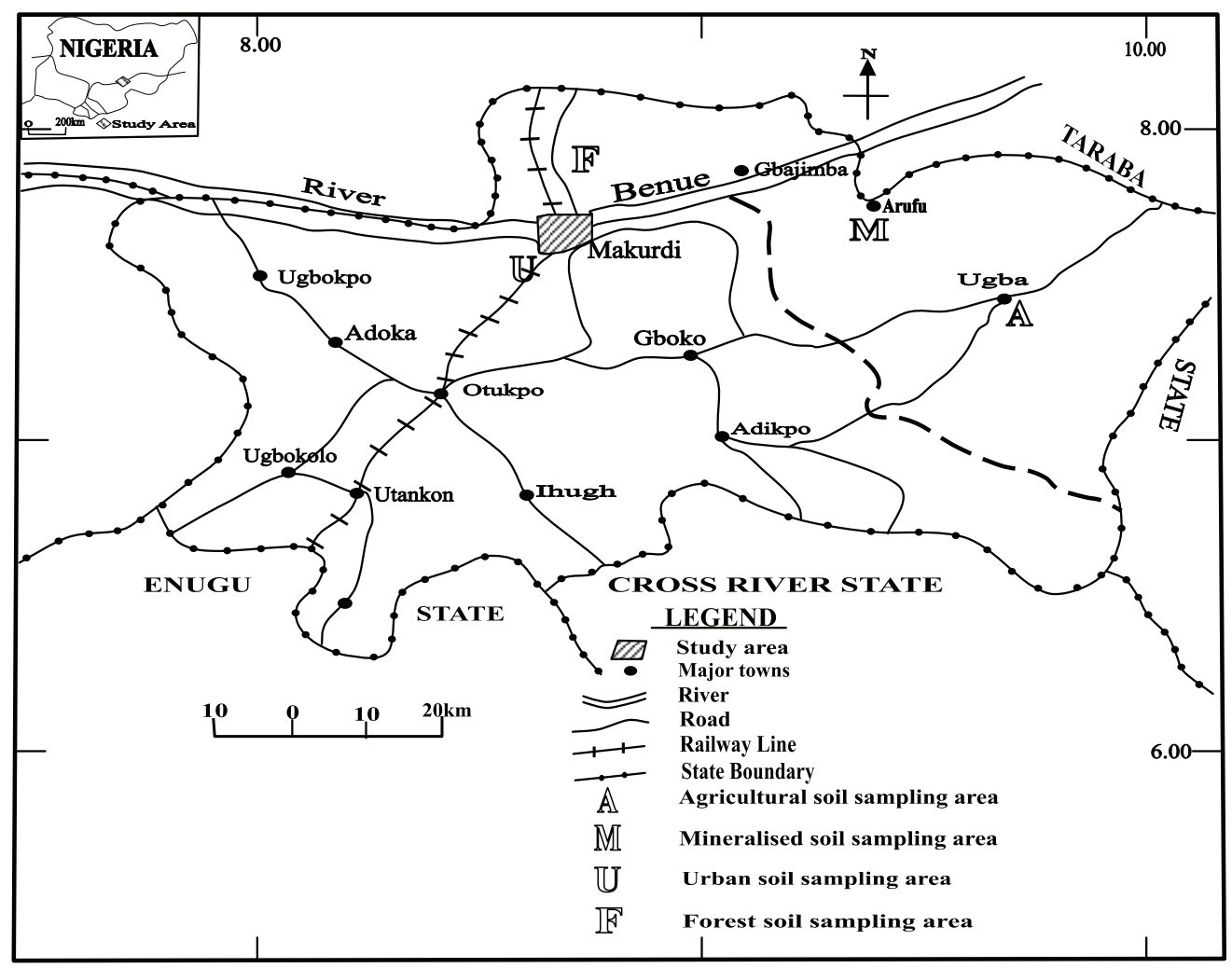

Figure 1. Map of Benue state showing showing the study sites 
constitute about $40 \%$ while swamps, rivers and open land cover about $53 \%$. As in many urban centers in developing countries, poor land use planning, lack of proper disposal facilities for sewage and solid wastes as well as high traffic congestion characterizes Makurdi town. The population in the town is unevenly distributed such that commercial, industrial, agricultural, recreational, administrative and residential areas are scattered all over the town and these are point sources of heavy metals [16] into the soil. Soil samples collected here were termed urban soils.

Site C (Ugba) is a rural settlement near Zaki-Biam and is well known for its intensive farming. As in many rural areas, farming in Ugba is characterized by poor land-use planning and indiscriminate application of fertilizer, biocides and manures with potential risk of heavy metal contamination [18]. Samples were collected from selected farms in Ugba using soil traverse reconnaissance data. The farms selected reflect the geochemical range of elements of interest to evaluate the agricultural significance of metal contamination. Samples collected from this site were termed agricultural soils.

Site D (Forest) is a forest reserve along the MakurdiLafia road that is not open to the public. The site is selected to serve as control. The levels of heavy metals in forest soils were considered as "present background values" as the original background values have changed since due to processes of soil formation as well as natural contributions from wind blown dust and wild fires.

\section{Materials and Methods}

Composite surface soil samples $(0-6 \mathrm{~cm})$ were collected from the four representative sites using an auger and stored in properly labeled polyethylene bags. They were air-dried at room temperature $\left(21-27^{\circ} \mathrm{C}\right)$ for seven days and later oven-dried at $100^{\circ} \mathrm{C}$ for three hours to obtain a constant weight. The soil samples were mechanically ground and sieved to obtain $<2 \mathrm{~mm}$ fraction. A fraction of the soil was drawn from the bulk soil $(<2 \mathrm{~mm}$ fraction) and reground to obtain $<200 \mu \mathrm{m}$ fraction using a mortar and pestle and then digested using aqua-regia. Analysis of the heavy metals ( $\mathrm{Zn}, \mathrm{Cu}, \mathrm{As}, \mathrm{Pb}$, and $\mathrm{Cd}$ ) was in duplicate, using atomic absorption spectrophotometer (AAS -bulk scientific model 210) from Soil Science Department University of Agriculture, Makurdi. The heavy metals analysed ( $\mathrm{Zn}, \mathrm{Cu} \mathrm{As}, \mathrm{Pb}$ and $\mathrm{Cd})$ are among those considered most problematic in terms of environmental pollution and toxicity [19]. The level of precision of the method used for the analyzed metals ranged between $\pm 5-10 \%$.

\section{Data Evaluation}

For the assessment of the heavy metal contamination in the study sites, some quantitative indices were used to describe the concentration trends and also to allow for easy comparison between the determined parameters. The indices used were anthropogenic factor (AF) and pollution index (PI).

Anthropogenic factor (AF) reflects the degree of contamination relative to the average composition of the respective metal in soils or to a measured background value from geologically similar but uncontaminated area. It is expressed as

$$
\mathrm{AF}=\mathrm{Cm} / \mathrm{Bm}
$$

Where $\mathrm{Cm}$ is the measured concentration in soil and $\mathrm{Bm}$ is the background concentration of the metal, " $\mathrm{m}$ ". $\mathrm{Bm}$ values are either taken from the literature or directly determined from a geological similar but uncontaminated area.

The Pollution index (PI) has been used to evaluate the degree of multi-element contamination. This is considered a better method of evaluation because heavy metals contamination in the surface environment is associated with a cocktail of contaminants rather than one element [20]. Although a variety of PI is used by researchers, the basic concept is the same. In this study, the PI of soils was computed using average levels in soils tolerable to plants growth given by [21]. The equation is as follows:

$$
\begin{aligned}
\mathrm{PI}= & \{(\mathrm{As} / 20)+(\mathrm{Cd} / 3)+(\mathrm{Cu} / 100) \\
& +(\mathrm{Pb} / 100)+(\mathrm{Zn} / 300)\} / 5
\end{aligned}
$$

Taking As $(\mathrm{mg} / \mathrm{kg})$ as example. When PI values are $>$ 1.0 the soils are considered to be contaminated by anthropogenic inputs.

So we relay on the methods used in the present study for quality assessment with general applicability and validity for now.

\section{Discussion of Results}

\subsection{Metal Concentration in Soils}

The mean concentrations of $\mathrm{As}, \mathrm{Zn}, \mathrm{Cu}, \mathrm{Pb}$ and $\mathrm{Cd}$ in the various soil categories are presented in Table 1 alongside with their general average abundance in soil compiled by Cox [19]. Significant levels of trace elements were found in mineralized and urban areas, with mean values of 171 $\mathrm{mg} / \mathrm{kg}$ and $170 \mathrm{mg} / \mathrm{kg}(\mathrm{Zn}), 70 \mathrm{mg} / \mathrm{kg}$ and $109 \mathrm{mg} / \mathrm{kg}$ $(\mathrm{Cu}), 58 \mathrm{mg} / \mathrm{kg}$ and $45 \mathrm{mg} / \mathrm{kg}(\mathrm{Pb}), 16 \mathrm{mg} / \mathrm{kg}$ and 10 $\mathrm{mg} / \mathrm{kg}$ (As), and $1.8 \mathrm{mg} / \mathrm{kg}$ and $1.2 \mathrm{mg} / \mathrm{kg}(\mathrm{Cd}) \mathrm{respec}-$ tively. Agricultural soils contained moderate levels of trace metals with average values of $150 \mathrm{mg} / \mathrm{kg}(\mathrm{Zn}), 67$ $\mathrm{mg} / \mathrm{kg}(\mathrm{Cu}), 52 \mathrm{mg} / \mathrm{kg}(\mathrm{Pb}), 18 \mathrm{mg} / \mathrm{kg}$ (As), and 0.8 $\mathrm{mg} / \mathrm{kg}(\mathrm{Cd})$. Forest soils are the least enriched in trace metals with mean values of $85 \mathrm{mg} / \mathrm{kg}(\mathrm{Zn}), 54 \mathrm{mg} / \mathrm{kg}$ $(\mathrm{Cu}), 36 \mathrm{mg} / \mathrm{kg}(\mathrm{Pb}), 8 \mathrm{mg} / \mathrm{kg}(\mathrm{As})$, and $6 \mathrm{mg} / \mathrm{kg}(\mathrm{Cd})$. The results revealed elevated levels of heavy metals relative to world mean abundance of 36-100 mg/kg ( $\mathrm{Zn}$ ), 20 $-50 \mathrm{mg} / \mathrm{kg}(\mathrm{Cu}), 17-30 \mathrm{mg} / \mathrm{kg}$ (Pb), 2-10 mg/kg (As), and $0.1-0.5 \mathrm{mg} / \mathrm{kg}(\mathrm{Cd})$, indicating that the original background 
values of all soil categories have changed since because of soil forming processes as well as anthropogenic inputs (from human activities). Metals also occur in relatively high concentrations in urban, mineralized and agricultural soils as compared to the forest soils indicating that the forest soils have suffered least anthropogenic inputs and the metal values in the forest soil could be used as "present background values" in soil quality evaluation.

Zinc has the highest concentration in soils with mean values ranging from $85 \mathrm{ppm}$ in forest soil to $171 \mathrm{ppm}$ in urban soil compared to world mean abundance of $70 \mathrm{ppm}$. Copper has average concentrations ranging from $54 \mathrm{ppm}$ in forest soils to $109 \mathrm{ppm}$ in urban soils compared to world mean abundance of $55 \mathrm{ppm}$. Lead has mean values of $36 \mathrm{ppm}$ for forest soil, $45 \mathrm{ppm}$ for urban soil, $52 \mathrm{ppm}$ for agricultural soil and $58 \mathrm{ppm}$ for mineralized soil as compared to world mean abundance value of $13 \mathrm{ppm}$. Arsenic and Cadmium have mean values of $8 \mathrm{ppm}$ and $0.6 \mathrm{ppm}$ for forest soil, $10 \mathrm{ppm}$ and $1.2 \mathrm{ppm}$ for urban soils; $16 \mathrm{ppm}$ and $1.8 \mathrm{ppm}$ for mineralized soils and $18 \mathrm{ppm}$ and $0.8 \mathrm{ppm}$ for agricultural soils as compared to world mean abundance values of $2 \mathrm{ppm}$ and $0.2 \mathrm{ppm}$ respectively. The order of concentration of metals in soils is $\mathrm{Zn}>\mathrm{Cu}>$ $\mathrm{Pb}>\mathrm{As}>\mathrm{Cd}$. The indications of contamination are clearly revealed by the respective metal concentrations with values above world mean values (Table 1).

With respect to the mean concentrations in the various soil types, urban soils have the highest concentration of $\mathrm{Zn}$ and $\mathrm{Cu}$; mineralized soils have highest values for $\mathrm{Pb}$, $\mathrm{Zn}$, and $\mathrm{Cd}$ while agricultural soils have the highest value of As. (Table 1). The order of concentration of heavy metals in the soil types is mineralized soils $>$ urban soils $>$ agricultural soils $>$ forest soils.

Zinc exhibits high levels of variations in all soils with large standard deviation values ( \pm 34 to 107$)$ while As and $\mathrm{Cd}$ concentrations are least variable as indicated by low standard of deviation values $(< \pm 10)$. Other heavy metals exhibit moderate variability with standard deviation values ranging from \pm 20 to \pm 53 . Large variations imply great heterogeneity of metals in soils while low variations show more or less homogeneous distribution of metal in the soil. On the basis of soil type, urban soils are more variable exhibiting highest variability for As, $\mathrm{Cu}$ and $\mathrm{Cd}$; followed by agricultural soils with highest variability for $\mathrm{Zn}$ and $\mathrm{Pb}$. Forest soils are least variable. The order of variability is urban soils $>$ agricultural soils $>$ mineralized soil $>$ forest soils and may reflect varying sources of anthropogenic inputs.

Correlation coefficients (r) between different heavy metals were calculated in order to understand their covariation (Table 2).

Significant correlations $(\mathrm{P} \leq 0.05)$ occurred between $\mathrm{Zn}-\mathrm{Pb}(0.64)$ and $\mathrm{Cu}-\mathrm{As}(0.6)$ in mineralized soil, between $\mathrm{Zn}-\mathrm{Cu}(0.64), \mathrm{Zn}-\mathrm{Cd}(0.5)$ and $\mathrm{Cu}-\mathrm{Cd}(0.6)$, in urban soils, As-Cd (0.61) in agricultural soils and $\mathrm{Zn}-\mathrm{Pb}$ $(0.82)$ in forest soils (Table 2). Strong correlations between elements imply similar geochemical controls in the surface environment. This is a strong indication that the sources of these metals are related to common anthropogenic rather than geogenic inputs, which would have been dependent on geochemical factors including variables such as soil properties $\mathrm{pH}$, Eh, etc, which control metal behaviour in the soil.

\subsection{Assessment of Metal Contamination}

Quantitative evaluation of soil quality in the study was carried out using indices such as Anthropogenic Factors (AF) and Pollution Index (PI). The average crustal abundance [22] and levels of metals obtained from this study were used as "background values" and "present background" values in order to give a comparative idea about the quality and degree of heavy metal contam- ination of surface soils of Benue State. Estimated values of anthropogenic factors (AF) for the heavy metals determined in soils samples with respect to the average crustal abundance were generally greater than one and range from 4-9 (As), 1.2-2.4 (Zn), 1.1-2.2 (Cu), 1.8-2.9 (Pb) and 1.4-3.6 (Cd) (Table 3).

This indicates a, 1 to 10 fold enrichment compared to average crystal abundance. Mineralized soils have the highest enrichment factors for $\mathrm{Zn} \mathrm{Pb}$ and $\mathrm{Cd}$, urban soils are most enriched in $\mathrm{Cu}$, while agricultural soils are the most enriched in As. In all, forest soils are the least enriched in all analyzed heavy metals. This shows that all

Table 1. Mean \pm S.D. values of analyzed heavy metals $(\mathrm{mg} / \mathrm{kg})$ in soils in parts of Benue State, Nigeria

\begin{tabular}{ccccccccc}
\hline Site & Location & Description & $\mathrm{N}$ & $\mathrm{Zn}$ & $\mathrm{Cu}$ & $\mathrm{Pb}$ & $\mathrm{As}$ & $\mathrm{Cd}$ \\
\hline $\mathrm{A}$ & Arufu & Mineralized soil & 40 & $171 \pm 83$ & $70 \pm 83$ & $58 \pm 28$ & $16 \pm 5$ & $1.8 \pm 5$ \\
$\mathrm{~B}$ & Makurdi & Urban soil & 40 & $170 \pm 107$ & $109 \pm 53$ & $45 \pm 31$ & $10 \pm 8$ & $1.2 \pm 8$ \\
$\mathrm{C}$ & Ugba & Agricultural soil & 40 & $150 \pm 94$ & $67 \pm 23$ & $52 \pm 35$ & $18 \pm 6$ & $0.8 \pm 3$ \\
$\mathrm{D}$ & Makurdi & Forest soil & 20 & $85 \pm 34$ & $54 \pm 31$ & $36 \pm 20$ & $8 \pm 3$ & $6.0 \pm 3$ \\
\hline Crustal average* & & & 70 & 55 & 13 & 0.2 & 0.5 \\
\hline \multicolumn{2}{l}{ Common range in soils** } & & $36-100$ & $20-50$ & $17-30$ & $2-10$ & $0.5-10$ \\
\hline
\end{tabular}

$\mathrm{N}=$ number of samples; *Bowen, 1979 [22]; **Cox, 1995 [21] 
Table 2. Correlation coefficients between heavy metals of soil studied

\begin{tabular}{|c|c|c|c|c|}
\hline A & $\mathrm{Zn}$ & $\mathrm{Cu}$ & $\mathrm{Pb}$ & $\mathrm{Cd}$ \\
\hline \multicolumn{5}{|c|}{ A. Mineralized soils $(n=40)$} \\
\hline As & 0.31 & $0.60^{*}$ & 0.45 & $0.56^{*}$ \\
\hline $\mathrm{Zn}$ & & 0.26 & $0.70^{*}$ & 0.01 \\
\hline $\mathrm{Cu}$ & & & 0.37 & 0.25 \\
\hline $\mathrm{Pb}$ & & & & 0.12 \\
\hline \multicolumn{5}{|c|}{ B. urban soil $(n=40)$} \\
\hline As & 0.42 & 0.18 & 0.30 & 0.12 \\
\hline $\mathrm{Zn}$ & & $0.64 *$ & -0.20 & $0.52 *$ \\
\hline $\mathrm{Cu}$ & & & 0.06 & $0.56^{*}$ \\
\hline $\mathrm{Pb}$ & & & & -0.18 \\
\hline \multicolumn{5}{|c|}{ C. Agricultural soil $(n=40)$} \\
\hline As & 0.23 & 0.30 & 0.41 & $0.61 *$ \\
\hline $\mathrm{Zn}$ & & -0.20 & -0.23 & -0.10 \\
\hline $\mathrm{Cu}$ & & & 0.31 & 0.02 \\
\hline PI & & & & 0.12 \\
\hline \multicolumn{5}{|c|}{ D. Forest soil $(\mathrm{n}=20)$} \\
\hline As & 0.36 & 0.24 & 0.46 & 0.21 \\
\hline $\mathrm{Zn}$ & & 0.08 & $0.82 *$ & 0.36 \\
\hline $\mathrm{Cu}$ & & & 0.05 & 0.17 \\
\hline $\mathrm{Pb}$ & & & & 0.22 \\
\hline
\end{tabular}

Indicates significant difference at $\mathrm{P}<0.05$

Table 3. Summary of quantitative indices with respect to metal contamination in surface soil samples in parts of Benue state, Nigeria

\begin{tabular}{|c|c|c|c|c|c|c|c|}
\hline \multirow[b]{2}{*}{ Site } & \multirow[b]{2}{*}{ Description } & \multicolumn{5}{|c|}{$\mathbf{A F}$} & \multirow[b]{2}{*}{ PI } \\
\hline & & $\mathrm{Zn}$ & $\mathrm{Cu}$ & $\mathrm{Pb}$ & As & $\mathrm{Cd}$ & \\
\hline A & Mineralized soil & 2.4 & 1.4 & 2.9 & 8.0 & 3.6 & 0.6 \\
\hline B & Urban soil & 2.4 & 2.2 & 2.3 & 5.0 & 2.4 & 0.6 \\
\hline $\mathrm{C}$ & Agricultural soil & 2.3 & 1.4 & 2.6 & 9.0 & 1.6 & 0.6 \\
\hline $\mathrm{D}$ & Forest soil & 1.2 & 1.0 & 1.8 & 4.0 & 1.4 & 0.4 \\
\hline
\end{tabular}

$\mathrm{AF}=$ Anthropogenic factor, $\mathrm{PI}=$ pollution index

representative soil types are enriched in heavy metals relative to mean crustal abundance. The relative enrichment in forest soils where human activities are restricted could be attributed to general enrichment through soil forming processes as well as deposition from air by emissions through automobile exhaust and application of biocides which are wide spread in Nigeria [23]. Natural sources of heavy metals such as windblown dust and wildfires might have also contributed to heavy metal enrichment in forest soils. This is consistent to the assertion by [24] that a certain amount of contamination of soil through deposition from the air is unavoidable.

Quantification of the overall contamination of the soils (Table 3, Figure 2) shows that about $75-90 \%$ As, 45$70 \% \mathrm{~Pb}, 53-60 \% \mathrm{Zn}, 37-72 \% \mathrm{Cd}$ and $7.4-54 \% \mathrm{Cu}$ are derived form anthropogenic inputs, confirming As as the most enriched element and $\mathrm{Cu}$ as the least enriched (Figure 3). The levels of heavy metals derived form anthropogenic inputs (Figure 2) for the various soil categories is as follows:

Site A (mineralized soil) As $(87.50 \%)>\mathrm{Cd}(72 \%)>$ $\mathrm{Pb}(65 \%)>\mathrm{Zn}(60 \%)>\mathrm{Cu}(54 \%)$

Site B (Urban soils) As $(80 \%)>\operatorname{Zn}(60 \%) \geq \mathrm{Cd}(60 \%)$ $>\mathrm{Pb}(55 \%)>\mathrm{Cu}(54 \%)$

Site C (Agricultural soils) As $(90 \%)>\mathrm{Pb}(60 \%)>\mathrm{Zn}$ $(50 \%)>\mathrm{Cd}(40 \%)>\mathrm{Cu}(54 \%)$

Site D (forest soils) As $(76 \%)>\mathrm{Pb}(44 \%)>\mathrm{Zn}(17 \%)$ $\geq \mathrm{Cd}(17 \%)>(\mathrm{Pb} \mathrm{13 \%})>\mathrm{Cu}(7.4 \%)$ (Figure 2).

These patterns reveal that the order of anthropogenic inputs in soils of the study area is $\mathrm{As}>\mathrm{Pb}>>\mathrm{Zn} \geq \mathrm{Cd}>$ 
$\mathrm{Cu}$. In terms of soil types, the order is mineralized soil $>$ urban soils $>$ agricultural soils $>$ forest soils. Such trends of anthropogenic contamination are consistent with the estimated AF trends which reflects environmental contamination arising form unplanned land use pattern and mineralization in the study area.

\section{Summary and Conclusions}

Results of geochemical studies of surface soils in parts of Benue state revealed an overall enrichment of heavy metals relative to crustal abundance depending on the degree of anthropogenic inputs and source of heavy metals. In general the extent and seriousness of heavy metal pol-

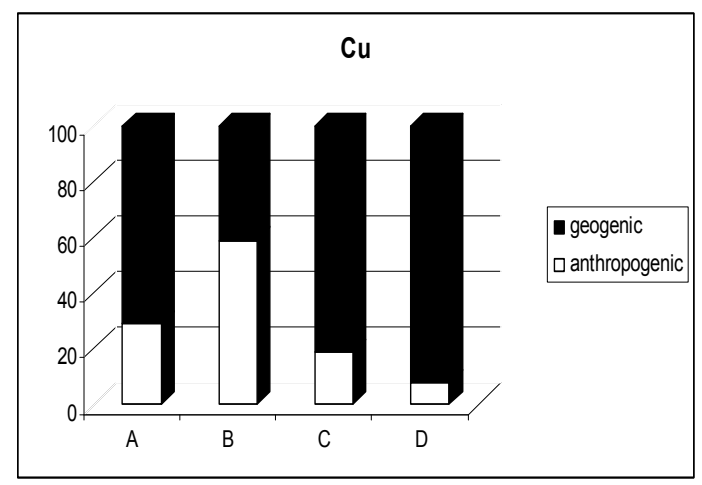

(a)

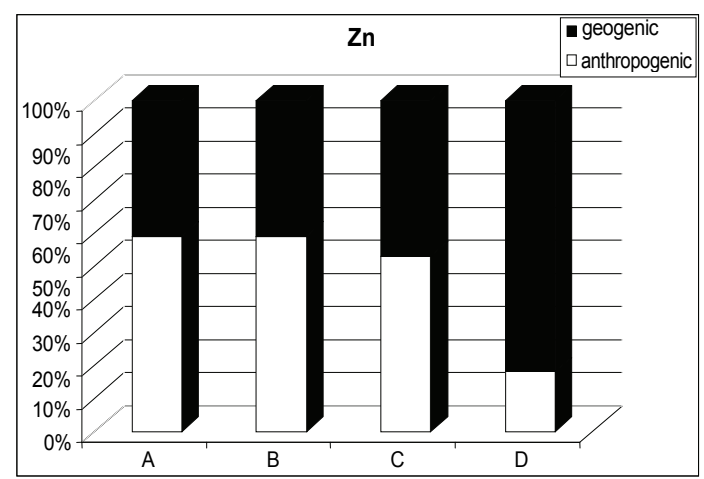

(b)

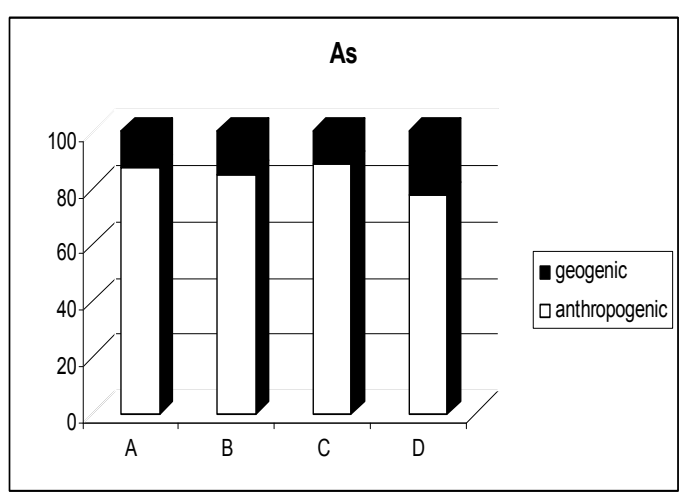

(c)

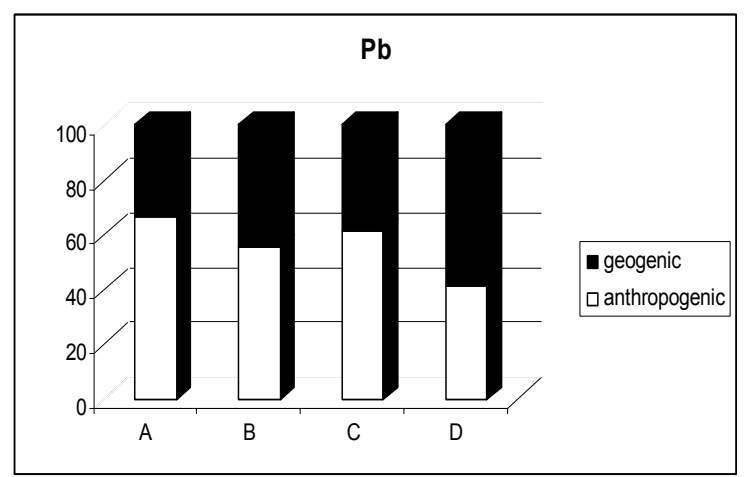

(d)

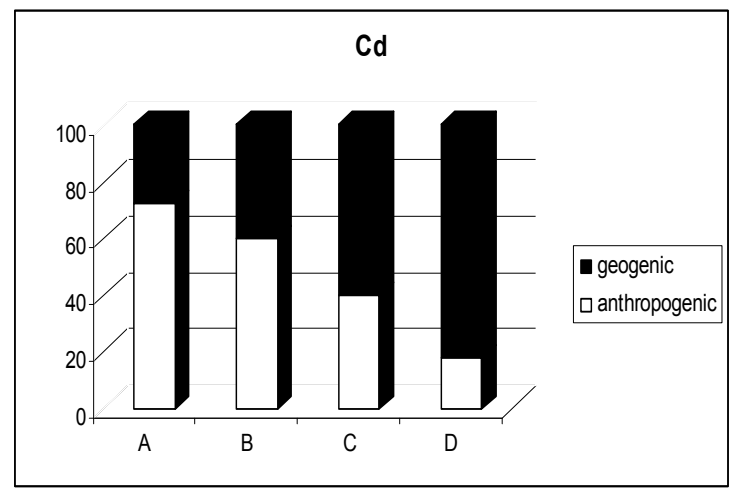

(e)

Figure 2. Anthropogenic contribution of heavy metals among soil types

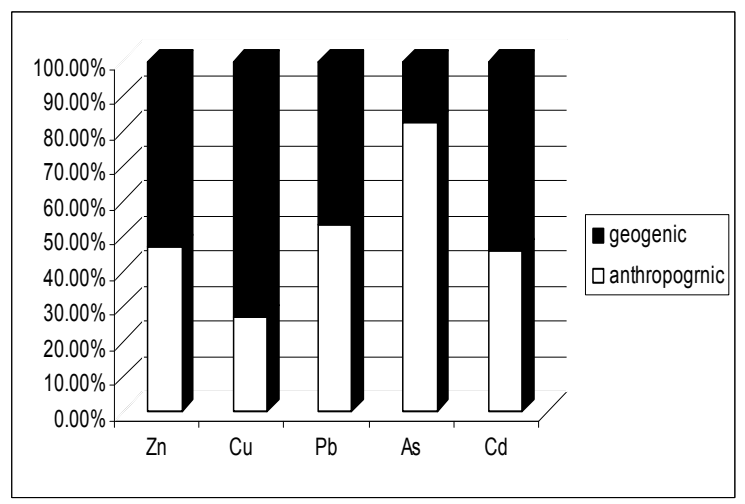

Figure 3. Distribution of input sources of heavy metals in soil samples

lution in mineralized and urban soil were the highest among the soil categories, followed by agricultural soils. Forest soils were subjected to the least impact form anthropogenic sources. Mineralized soils contained elevated levels of $\mathrm{Zn}, \mathrm{Pb}$ and $\mathrm{Cd}$ most probably released into the soil form the weathering of sulphide minerals form the mine waste. Urban soils accumulated $\mathrm{Cu}, \mathrm{Zn}$ and $\mathrm{Cd}$ most probably originating from commercial, domestic, 
agricultural and to a lesser extent industrial activities in the area. Agricultural soil accumulated As and to a lesser extent $\mathrm{Pb}$ and $\mathrm{Cd}$ most probably from the application of biocides, animal manures and fertilizers. The elevation of heavy metal content in the surface soils of Benue State seems to be related to urbanization and poor land planning and use.

Furthermore, quantification of degree of pollution revealed high anthropogenic contributions for As (82\%) and $\mathrm{Pb}(54 \%)$ indicating multiple sources for the heavy metals. Also anthropogenic inputs accounts for about $50 \%$ of $\mathrm{Zn}$ and $\mathrm{Cd}$ and $30 \% \mathrm{Cu}$. In addition the concept of pollution index gives important information on the extent and degree of multi-element contamination and can be applied to the evaluation of soils before their use for agriculture and production of food crops.

This study provides useful data on the present contamination of surface soils in relation to land use pattern in the study area and may form the basis for the formulation of pollution control and monitoring strategies as well as land use planning.

\section{Recommendation}

It is important to note that the challenge of heavy metal contamination lies in the fact that it is a by-product of development efforts and cannot be eliminated. Hence there is the need to continually monitor potential contaminated areas. A thorough geo-environmental study involving constant geochemical analysis, remotely sensed data and modeling must be a primary step in environmental monitoring in heavy metal contaminated areas. Monitoring is necessary to identify possible sources and degree of heavy metal contamination, select appropriate remedial measures and to manage land use in relation to mining, agriculture and urban development.

Since most soil contamination in agricultural land is associated wlth indiscriminate application of fertilizers and biocides, the most effective control strategy would be to educate farmers to apply precisely determined quantiies of these chemicals on their farms. This approach will reduce the amount of contaminants entering the soil and also save cost. Small scale, low-input farming offers an alternative to industrial, chemically intensive agriculture. Industries in the state should reduce contaminants through proper waste management, recycling and reuse of materials that might be discarded as waste. Prior to reclamation, unauthorized and unplanned cultivation of mine wastes and other contaminated areas be prohibited to reduce heavy metal mobility and bioavailability.

Effective land use planning involving the raising of public awareness and commitment to contamination control, seeking a compromise between developers and conservationist, pre-environmental impact assessment prior to developing a site and identification of specific uses for designated sites is recommended.

\section{REFERENCES}

[1] J. W. C. Wong, "Heavy Metal Contents in Vegetables and Market Garden Soils in Hong Kong," Environmental Technology, Vol. 17, 1996, pp. 407-410.

[2] K. G. Tiller, "Urban Soil Contamination in Australia," Australia Journal of soil Research, Vol. 30, No. 6, 1992, pp. 937-957.

[3] H. T. Chon, J. S. Ahn and M. C. Jung, "Seasonal Variations and Chemical Forms of Heavy Metals in Soils and Dusts from the Satellite Cities of Seoul, Korea," Environmental Geochemistry and Health, Vol. 20, 1998, pp. 77-86.

[4] M. C. Jung, I. Thornton and H. T. Chon, "Arsenic, Sb, and Bi Contamination of Soils, Plants, Waters and Sediments in the Vicinity of the Dalsung $\mathrm{Cu}-\mathrm{W}$ Mine in Korea," Science of the Total Environment, Vol. 295, No. 1-3, 2002, pp. 81-89.

[5] I. D. Pulford and C, Watson, "Phytoremediation of Heavy Metals Contaminated Land by Tree-A View," Environment International, Vol. 29, No. 4, 2003, pp. 529-540.

[6] M. H. Wong, "Ecological Restoration of Mine Degraded Soils with Emphasis on Metal Contaminated Soils," Chemosphere, Vol. 50, No. 6, 2003, pp. 775-780.

[7] W. W. Wenzel and F. Yockwer, "Accumulation of Heavy Metals in Plants Grown on Mineralized Soils of the Australian Alps," Environmental Pollution, Vol. 104, No. 1, 1999, pp. 145-155.

[8] A. Kabata-Pendias and H. Pendias, "Trace Elements in Soils and Plants," CRC Press, New York, 2001.

[9] A. Hursthouse, D. Tognareli, P. Tucker, F. A. Marsan, C. Martini, L. Madrid, F. Madrid and E. Diaz-Barrientos, "Metal Content of Surface Soils in Parks and Allotments from Three European Cities: Initial Plot Study Results," Land Contamination and Reclamation, Vol. 12, No. 3, 2004, pp. 189-197.

[10] B. Singh, "Heavy Metals in Soils: Sources, Chemical Reactions and Forms," In: D. Smith, S. Fityus and M. Allman, Eds., Proceedings of the 2nd Australia and New Zealand Conference on Environmental Geotechnics Newcastle, New South Wales, Australian Geochemical Society, Newcastle, 2001, pp. 77-93.

[11] F. Mapanda, E. N. Mangwayana, J. Nyamangara and K. E. Giller, "The Effect of Long-Term Irrigation Using Wastewater on Heavy Metal Contents of Soils Under Vegetable Harare, Zimbabwe," Agriculture, Ecosystems \& Environment, Vol. 107, No. 2-3, 2005, pp. 151-165.

[12] I. Thornton and J. Plant, "Regional Geochemical Mapping and Health in the U. K.," Journal of Geological Society, London, Vol. 137, No. 5, 1980, pp. 575-586.

[13] A. E. Edet and E. E. U. Ntekim, "Heavy Metal Distribution in Groundwater from Akwa Ibom State, Eastern Niger Delta, Nigeria-A Preliminary Pollution Assessment," Global Journal of Pure and Applied sciences, Vol. 2, No. 1, 1996, pp. 67-77.

[14] S. J. Salami, E. A. Akande and D. M. Zachariah, "Level of Heavy Metals in Soils and Lemon Grass in Jos, Bukuru 
and Environs, Nigeria," Global Journal of Pure and Applied Sciences, Vol. 13, No. 2, 2007, pp. 193-196.

[15] Q. Zhang, X. Shi, B. Huang, D. Yu, I. Oborn, K. Blomback, H. Wang, T. F. Pagella and F. L. Sinclair, "Surface Water Quality of Factory-Based and Vegetable Based Peri-Urban Areas in the Yangtze River Delta Region, China," CATENA, Vol. 69, No. 1, 2007, pp. 57-64.

[16] C. I. Adamu, T. Nyiategher and J. I. Angitso, "Metal Contamination at Dump Sites in Makurdi, Nigeria," Global Journal of Geological Science, Vol. 1, No. 1, 2003, pp. 85-93.

[17] "Nigerian Population Census Results (NPC)," 2006.

[18] J. O. Agbenin, "Phosphate Induced Zinc Retention in Semi Arid Soils," European Journal of Soil Science, Vol. 49, No. 4, 1998, pp. 693-700.

[19] P. A. Cox, "The Elements on Earth: Inorganic Chemistry in the Environment," Oxford University Press Inc., New York, 1995.
[20] H. T. Chon, J. S. Ahn and M. C. Jung, "Heavy Metal Contamination in the Vicinity of some Base Metal Mines in Korea-A Review," Geosystem Engineering, Vol. 1, No. 2, 1998, pp. 74-83.

[21] A. Kloke, "Content of Arsenic, Cadmium, Chromium, Fluorine, Lead, Mercury, and Nickel in Plants Grown on Contaminated Soils," United Nations-ECE Symposium, Geneva, 1979, pp. 51-53.

[22] H. J. M. Bowen, "Environmental Geochemistry of Elements," Academic Press, London, 1979.

[23] A. O. Oyewale and I. I. Funtua, "Lead, Copper and Zinc Levels in Soils along Kaduna-Zaria Highway, NigeriaEstimation of Pollution Level," Scientia, Vol. 2, No. 1, 2003, pp. 26-32.

[24] F. A .M. De Haan, "Soil Quality in Relation to Soil Pollution,” In: J. V. Lake, F. Willey, G. R. Bock and L. Ackril, Eds., Environmental Change and Human Health, Wiley, Chichester, Vol. 175, 1993, pp. 104-123. 